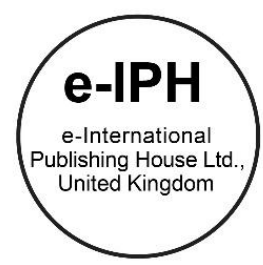

\title{
Tendency and Behaviour of Furniture Usage of Consumers in Thailand for Business Strategy Formation for Sustainable Environment
}

\author{
Ornwiriya Namsawat*, Yanin Rugwongwan \\ ${ }^{1}$ Arch.D. Student, Multidisciplinary Design Research Program, \\ ${ }^{2}$ Asst. Prof. Ph.D. program in a school of Interior Architecture, \\ Faculty of Architecture, King Mongkut's Institute of Technology Ladkrabang (KMITL), Thailand \\ onwiriya@gmail.com \\ Tel:+66881287759
}

\begin{abstract}
According to the problems of excessive consumption of natural resources and the increasing trend of manufacturing across the globe at present, the need for transformation to sustainable consumption and sustainable production has been put on centre stage. One of the solutions to these problems is conducting business operations with the responsibility to the environment to reduce environmental impacts by changing consumption patterns relative to the consumers. This will lead to the business strategy in Product-Service Systems for furniture business under the concept of the Green Business Model to meet the consumers' needs. This research is, thus, a study of the behavioural trends of furniture usage, an analysis on environmental awareness of consumers in Thailand, and a search for the methods to provide services that will be accepted by the consumers to incentivize them in having sustainable consumption behaviours.
\end{abstract}

Keywords: Environmental Friendly Furniture; Design for Environment; Sustainable Consumption; Behaviour of Furniture Usage

eISSN: 2398-4287@ 2017. The Authors. Published for AMER ABRA by e-International Publishing House, Ltd., UK. This is an open access article under the CC BYNCND license (http://creativecommons.org/licenses/by-nc-nd/4.0/). Peer-review under responsibility of AMER (Association of Malaysian Environment-Behaviour Researchers), ABRA (Association of Behavioural Researchers on Asians) and cE-Bs (Centre for Environment-Behaviour Studies), Faculty of Architecture, Planning \& Surveying, Universiti Teknologi MARA, Malaysia.

https://doi.org/10.21834/e-bpj.v2i6.952

\subsection{Introduction}

Thailand is classified as a developing country and a production base for industrial business. The majority of the business operations are the supply of product manufacturing or Original Equipment Manufacturing (OEM) to produce products according to the customers' design and specifications. The utilization of natural resources in the country is important including furniture, which is one of the Thai products that contribute to exports, and furniture-parts manufacturing of which $90 \%$ of the main materials are from natural resources. The current trend of consumer behaviour appears to be a shorter usage cycle of products, especially the use of furniture in businesses. Most pieces of furniture are not utilized until they become old or damaged but are replaced by the purchase of new furniture for aesthetic reasons and image changes (UAE. 2004). Based on the demand of consumers with changing behaviours in product usage over time, the trend of consumption in the modern world suggests that products are seen as an item that represents an image, social class identity, different levels of society and differences among people. Current marketing accordingly uses this idea as a strategy for a company's business operation which leads to products that are designed to be outdated quickly, encouraging consumers to change to new products in no time. This seems to have become a problem of accumulating end-of-life products which are discarded and difficult to manage, eradicate and destroy. In Thailand, the law and policy on the responsibility of manufacturing companies are still not clear. As a result, this issue will become a more accumulative problem in the future if it is not taken into consideration. The research from Oko-Institute in Germany found that the lifetime of electronic products begins to continually shorten

eISSN: 2398-4287@ 2017. The Authors. Published for AMER ABRA by e-International Publishing House, Ltd., UK. This is an open access article under the CC BYNCND license (http://creativecommons.org/licenses/by-nc-nd/4.0/). Peer-review under responsibility of AMER (Association of Malaysian Environment-Behaviour Researchers), ABRA (Association of Behavioural Researchers on Asians) and cE-Bs (Centre for Environment-Behaviour Studies), Faculty of Architecture, Planning \& Surveying, Universiti Teknologi MARA, Malaysia.

https://doi.org/10.21834/e-bpj.v2i6.952 
due to the increasing frequency of new product replacement cycles, and products that are intentionally designed to look old-fashioned tend to deteriorate quickly (Ala-Kurikka, 2015).

For those reasons, the researcher came up with the idea of environment-friendly product design with a combination of service methods which are efficient in being environmentally friendly in the furniture business. This is because the furniture business uses a high volume of both domestic and international raw materials in production, has some involvement in everyone's daily life and is a business group which is 1 of the nine creative industries (Kenan Institute Asia. 2009). In Thailand, there is still an opportunity for growth of future businesses under the concept of Green Business Model. Also, furniture is a product of which additional service methods can be thoroughly added in the complete life cycle of the product according to the different demands of furniture usage from various objectives of consumer groups. This article, thus, focuses on the consumer market concerning the behaviours and the importance of furniture in the pre-purchase phase, behaviours in the furniture encounter stage and behaviours at the end of product life. It analyzes the awareness of the environmental impacts of furniture and seeks ways to provide services that will be acceptable for consumers to promote sustainable consumption behaviours.

\subsection{Purpose of Research}

The objective of this article is to study the behavioural trends of furniture usage and analyze the awareness of the environmental impacts of the consumers in Thailand. It is a part of the research on the topic of "Design Strategies in Product-Service Systems for Environmental Sustainability of Thai Furniture Businesses" which is in working process at present.

\section{Objectives}

To study the behavioural trends of furniture usage and analyze the environmental awareness of consumers in Thailand. What are the behavioural trends of furniture usage among consumers in the business sector and in what aspects are they aware of the environmental impacts?

\section{Research Framework}

Regarding the stated hypothesis and objectives, the research framework is established in Figure 1 which shows the dimensions of factors influencing the furniture usage behavior and environmental awareness of consumers to provide the answers to the research questions and to apply the results to the design strategies in the Product-Service System which will create environmental friendliness in the Thai furniture industry.

\section{Target Group}

Business organizations (B2B)

Or customers who own businesses

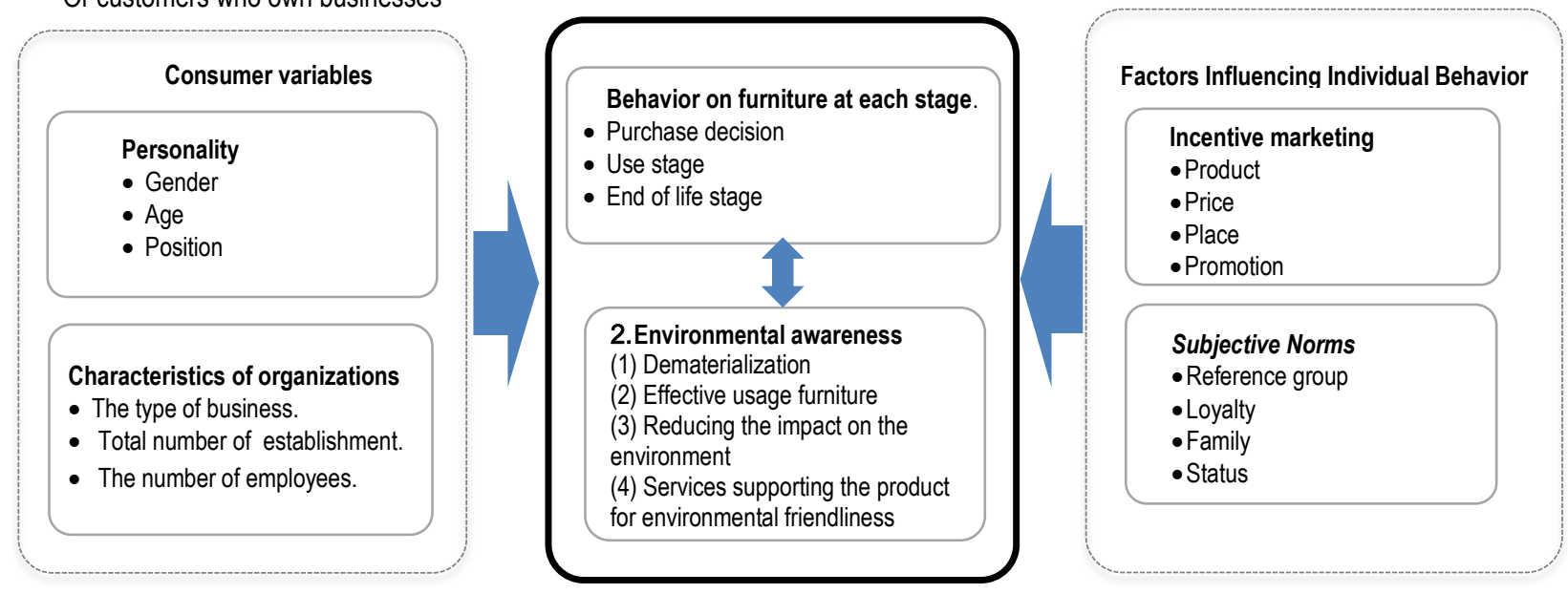

Fig. 1: Research Framework

\subsection{Literature Review}

\subsection{Green Business}

There is the increasing number of business firms and industrial entrepreneurs that recognize environmental management issues, and it has been set as the main issue in business strategies. Thus, capable of a long-run business management policies. There is possibility in the future that every firm must participate more or must implement various strategies to reduce environmental impact issues that cause by their products and services. Government policies and laws have realized the importance on the rise of manufacturing and consumption, which lead toward subsequent environmental issues. There is presently no any method that is a 
complete formula for simultaneous development of every products and services that changes or meeting any single elements will lead to adjustment of others Brezet, Bijma (2001) specified that each case of the products should receive consideration attentively especially even if it supposed to be the path for PSS designing which is generally used. Manzini and Vezzoli (2003) said that the true characteristic of Product-Service in green business approach which matches the idea of Tukker (2006) who informed that the environmental sustainability of the product-service will be strong by emphasizing the characteristic of choices to access the services by users (user-oriented services) and emphasizing the result (result-oriented services) which will create more sustainability for the environment than the approach which puts emphasis on the product (product-oriented service).

\section{End of Life (EOL)}

When there is better management at the end of life period (EOL), this results in lower environmental impact. Where, in some cases, Green business can stimulate changes in product design to offer convenient in EOL management. If EOL is managed by the third party, there will often be communication between EOL manager and manufacturer. (Fishbein and Young. 2000). However, examples in some cases show that EOL management method can create pressure on manufacturer or additional expenses for products that have high management price at the end of life period.

\subsection{Approach to meet customer needs and behaviors.}

Customer response principle - Product service systems are the principle that creates a combination of satisfaction responses from user-specific demands, which can be separated according to the various points as follows:

- It is a principle that promotes the search of product usage demand of customers and meets the customer's emotional satisfaction according to customer desire.

- Product service systems is a principle that promotes a higher level of user participation, which helps reduce environmental impact.

Lars Perner (2010) Have studied about the study of consumers helps business and organizations improve their marketing strategies by understanding issues such as how:

- Motivation and strategies in the decision-making of consumers vary between different products in the priority or level of interest they have in the products.

- $\quad$ Marketers can adapt and improve marketing campaigns and marketing strategies to reach consumers more effectively.

- External factors of how the consumer is influenced by his or her environment (e.g., culture, family)

3.3 Environmental design principles-Guidelines uses design working principle that is based on the foundation of design systems, which account for decreases of environmental impact in the products' life cycle .It uses a suitable amount of materials following the principle of dematerialization and can incorporate services into each element of product's usage period to obtain optimal results. Design principle can be divided according to the various points as follows:

- Reduces raw material resources, Dematerialization, at the beginning of the design process.

- Designs products to maximize its usage efficiency during its beginning and usage periods

- Creates guidelines to increase benefits from providing services that support more efficient product usage during its usage period.

- A design principle that accounts for the end of product lifecycle management during product end of life period.

- A beneficial improvement principle for providing services toward product end of life period.

\section{Classification of methods for reducing the environmental impact}

Our review has identified 20 papers that are directly related to the topic of Environmental Design. These have been analysed, interpreted, and summarized. From this five key findings have been established:

(1) Dematerialization

(2) Effective usage furniture

(3) Reducing the impact on the environment such as chemical pollution, increasing the amount of waste and the use of energy.

(4) Services supporting the product for environmental friendliness

Researchers have analyzed the design strategy for environmental Created Product-Service strategy from the combination of designing methods base on set PSS principle criteria and refers to the categorization suggested by Oksana (2004).

Table 1. Product-Service optimization strategies

\begin{tabular}{ll|ll}
\hline Product optimization strategies & \multicolumn{1}{c|}{ Environmental Goals } & Service optimization strategies & \multicolumn{1}{c}{ Environmental Goals } \\
\hline 1. Material substitution & (1) Dematerialization & $\begin{array}{l}\text { 1. Support services during design, } \\
\text { production of products }\end{array}$ & (4) Services supporting the product \\
\hline 2. Reduction of consumables & (1) Dematerialization & 2.Services at the point of sale & (4) Services supporting the product \\
\hline
\end{tabular}




\begin{tabular}{|c|c|c|c|}
\hline 3. Product life extension & (2) Effective usage furniture & 3. Help Desk - hot line on product & (4) Services supporting the product \\
\hline 4. Design for disassembly & (2) Effective usage furniture & $\begin{array}{l}\text { 4. Various concepts of product } \\
\text { use }\end{array}$ & (4) Services supporting the product \\
\hline 5. Design for disposability & $\begin{array}{l}\text { (3) Reducing the impact on the } \\
\text { environment }\end{array}$ & 5. EOL services & (4) Services supporting the product \\
\hline 6. Waste source reduction & $\begin{array}{l}\text { (3) Reducing the impact on the } \\
\text { environment }\end{array}$ & 6. Updates/upgrades Services & (4) Services supporting the product \\
\hline 7.Toxic and waste product reduction & $\begin{array}{l}\text { (3) Reducing the impact on the } \\
\text { environment }\end{array}$ & $\begin{array}{l}\text { 7. Spare parts and consumables } \\
\text { Delivery }\end{array}$ & (4) Services supporting the product \\
\hline 8. Energy use reduction & $\begin{array}{l}\text { (3) Reducing the impact on the } \\
\text { environment }\end{array}$ & $\begin{array}{l}\text { 8. Leasing , Renting, Sharing and } \\
\text { Pooling services }\end{array}$ & (4) Services supporting the product \\
\hline 9. Modular design for upgrading & (2) Effective usage furniture & 9. Support transportation & (4) Services supporting the product \\
\hline 10. Design for recyclability & $\begin{array}{l}\text { (3) Reducing the impact on the } \\
\text { environment }\end{array}$ & 10. Maintenance services & (4) Services supporting the product \\
\hline 11. Design for reusability & $\begin{array}{l}\text { (3) Reducing the impact on the } \\
\text { environment }\end{array}$ & 11. Recycling and take back & (4) Services supporting the product \\
\hline 12. Design for easy repair & $\begin{array}{l}\text { (3) Reducing the impact on the } \\
\text { environment }\end{array}$ & 12. Extended warranty & (4) Services supporting the product \\
\hline 13. Design for integrate functions & (2) Effective usage furniture & 13. Financial services & (4) Services supporting the product \\
\hline
\end{tabular}

\subsection{Methodology}

\section{Research patterns and procedures}

In this study, the researcher has considered and set the pivotal criteria of consumers who are the target consumers. The selected customers are corporative clients, B2B business organizations and consumers or customers who own businesses and have the authority to make decisions on the purchase of furniture for working purposes and decoration for their business benefit. The sample size of the customers who purchase furniture for decoration contributing to their business benefit is categorized by the size of the business and the number of employees, which can be divided into three groups as follows;

1. Large business $L$ refers to a company with more than 200 employees

2. Medium business $M$ refers to a company with 50-200 employees

3. Small business $S$ refers to a company with less than 50 employees

There may still be some other different factors such as government organization or private organization, difference in the business types and the number of years of operation of the company, which can be relevant factors for consideration.

Step 1 Create the questionnaire and questions for the interview which is developed by the questions of the variables in the research framework as shown in Figure 1.1. This will lead to an analysis of the behaviors and the environmental awareness of the consumers.

Step 2 Carry out site surveys to gather the information by inquiring the consumers at 50 companies in Bangkok. The consumers are classified by the size of the businesses $(S, M, L)$.

Step 3 Summarize the data analysis, bring the results from the questionnaires to explain the outcomes using analytical methods by classifying the data, explaining the variables and describing the quantitative correlation with statistical and percentage methods.

\section{Study Area}

The researcher has collected data from consumers who are targeted in this research. Determined by size of business $(S, M, L), 50$ companies in Bangkok as shown in table 2

\subsection{Result}

The research questionnaire consisted of 50 samples from business executives or who has the authority to decide to purchase furniture, it was found that (1) Gender: the number of females is more than males 28 females (56\%), 22 males (44\%); (2) Age: They were aged between 41-50 years old (22\%); (3) Duration of business operation: it was found that (20\%) were working time ranged from 2-5 years and (4) Size of business: it was found that (33\%) were small business, as shown in Table 2. The research results in terms of basic features that influence furniture products by using frequency percentage found that (1) the reason for buying new furniture is due to old furniture that is worn out; (2) the frequency in buying the furniture is within 3 years/time; (3) the information channels for buying the furniture are the internet and websites; (4) the time period for searching information to make a decision is 2-4 weeks; (5) the number of stores when comparing brands and stores is 2-3 stores; (6) the majority of product purchases take place in a department store; (7) the person who influences the furniture buying decision is self-determination; (8) the payment method is by credit card; (9) the type of worn-out furniture that is most often changed is a chair; (10) the problem that is found in using the furniture is bad quality material, easy to break in a short time; and (11) the lifetime of furniture that the majority of consumers need is 5-10 years. 
Table 2. Sample Characteristic

\begin{tabular}{llc}
\hline Variables & & $(\mathrm{n}=50)$ \\
\hline Gender & Male & $22(56.0 \%)$ \\
\multirow{2}{*}{ Age } & Female & $28(44.0 \%)$ \\
& $20-30$ years & $13(26 \%)$ \\
\multirow{4}{*}{ number of years of operation } & $31-40$ years & $15(30 \%)$ \\
& $41-50$ years & $22(44 \%)$ \\
& $<1$ years & $3(6 \%)$ \\
\multirow{4}{*}{ size of business } & $2-5$ years & $20(40 \%)$ \\
& $6-10$ years & $9(18 \%)$ \\
& $>10$ years & $18(36 \%)$ \\
& $\mathrm{S}$ & $33(66 \%)$ \\
& $\mathrm{M}$ & $14(28 \%)$ \\
\hline
\end{tabular}

Table 3. The table shows the mean and standard deviation on the awareness of the environmental impacts of the consumers through of used furniture under the principle of environmental friendliness between gender groups.

\begin{tabular}{|c|c|c|c|c|c|c|}
\hline \multirow{2}{*}{$\begin{array}{l}\text { The awareness of environmental impact on furniture } \\
\text { principle of environmental friendliness }\end{array}$} & \multicolumn{2}{|c|}{ Male $(\mathrm{N}=22)$} & \multicolumn{2}{|c|}{ Female $(\mathrm{N}=28)$} & \multirow[t]{2}{*}{$t$-value } & \multirow[t]{2}{*}{$p$} \\
\hline & Mean & S.D. & Mean & S.D. & & \\
\hline Over all & 3.51 & .219 & 3.34 & 3.51 & $2.224^{*}$ & $.031^{*}$ \\
\hline Dematerialization & 3.51 & .261 & 3.23 & .508 & $2.512^{*}$ & $.016^{*}$ \\
\hline Effective usage & 3.51 & .460 & 3.24 & .453 & $2.083^{*}$ & $.043^{*}$ \\
\hline $\begin{array}{l}\text { Reducing the impact on the environment (chemical pollution, increasing the amount of } \\
\text { waste and the use of energy) }\end{array}$ & 3.00 & .360 & 2.87 & .501 & 1.045 & .301 \\
\hline Services supporting the product for environmental friendliness & 4.02 & .355 & 4.01 & .279 & 0.013 & .990 \\
\hline
\end{tabular}

${ }^{*} p<.05$ is the level of significance

From the data analysis about the awareness of the effect to the environment through the behavior of using furniture under the environmental-friendly principle by using t-test and the gender variable, it was found that males and females have an overall different level of awareness of the effect to the environment through the behavior of using the furniture under the environmental-friendly principle with a statistical significance of $0.5\left(p<.05=.00{ }^{*}\right)$ by which males have an average level of awareness of the effect to the environment in 4 aspects, which is more than females. When considering the aspect of the environmental-friendly principle, it is found that males and females have a different level of awareness of the effect to the environment in terms of Dematerialization and Effective Usage with a statistical significance of 0.05 From the report charts that show the data of the average point of the awareness of the effect to the environment in Figure 2, it can be clearly seen that males have a high level of average points in all aspects, except in Reducing the impact on the environment, which is at a moderate level. Females have a moderate level of average points in all aspects, except in placing importance on Services supporting the product for environmental friendliness, which had a high average point level

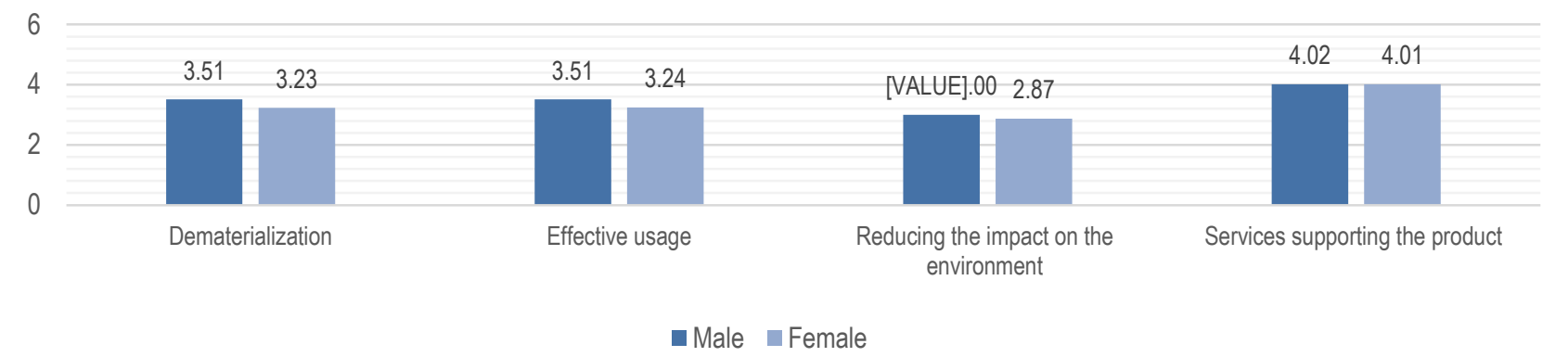

Fig. 2: Comparing of four elements of the data of the principle of environmental friendliness: Dematerialization, Effective usage,

Reducing the impact on the environment, Services supporting the product for environmental friendliness.

The data analysis found that the average of the awareness of the effect to the environment through the behavior of using furniture of males is higher than the average of females in all aspects according to the factors of product lifetime, which are (1) Pre-purchase; (2) Use Stage; and (3) End of life stage in which males placed a higher importance with a higher average than females, and a difference of importance was also found in the factors of providing service in Use stage and providing service in End of life stage. From the data analysis by using t-test and the gender variable, it was found that males and females have a different level of awareness of the effect to the environment through the behavior of using furniture in the period of End of life stage with a statistical significance of 0.05 ( $p<$ $.05=.000^{*}$ ) by which males have a higher average level of awareness of the effect to the environment than females and a higher averages in all periods of product lifetime as shown in the report chart that shows the data of the average point in awareness of the effect to the environment in Figure 3. 
Table 4. The table shows the mean and standard deviation on the awareness of the environmental impacts of the consumers through of used furniture in each period of product lifecycle between gender groups.

\begin{tabular}{|c|c|c|c|c|c|c|}
\hline \multirow{2}{*}{$\begin{array}{l}\text { The awareness of environmental impact on furniture } \\
\text { Period of product lifecycle }\end{array}$} & \multicolumn{2}{|c|}{ Male $(\mathrm{N}=22)$} & \multicolumn{2}{|c|}{ Female $(\mathrm{N}=28)$} & \multirow[t]{2}{*}{$t$-value } & \multirow[t]{2}{*}{$p$} \\
\hline & Mean & S.D. & Mean & S.D. & & \\
\hline Pre-purchase stage & 3.19 & .429 & 3.11 & .341 & 7.03 & .486 \\
\hline Use stage & 3.27 & .412 & 3.07 & .421 & 1.626 & .110 \\
\hline End of life stage & 3.09 & .487 & 2.63 & .560 & $3.069^{*}$ & $.004^{*}$ \\
\hline
\end{tabular}

${ }^{*} p<.05$ is the level of significance

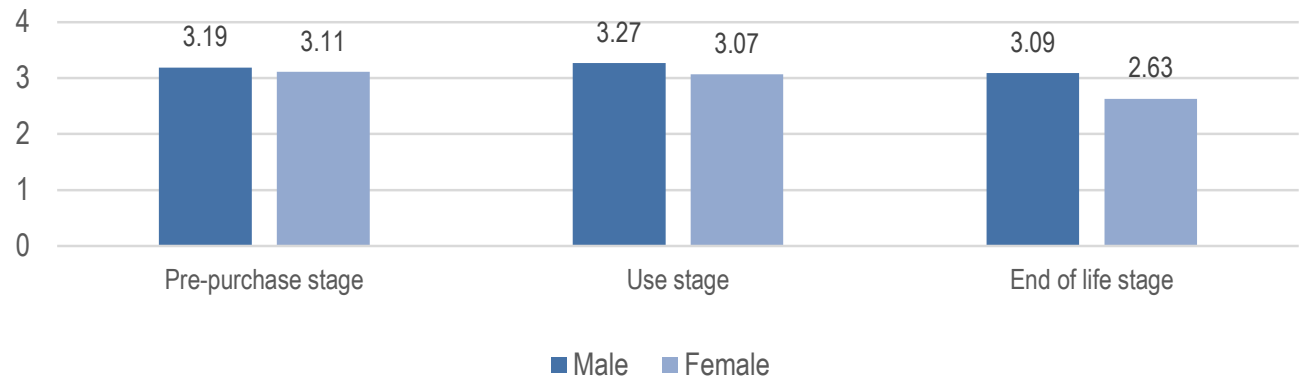

Fig 3: Comparing of three elements during product lifecycle: Pre-purchase stage, Use stage, End of life stage.

The comparative analysis results of the level of importance for features of the furniture showed that males and females placed the highest level of importance in terms of the features of furniture products in the same 3 aspects, which are (1) Functionality; (2) Size that is suitable for space; and (3) Quality of materials as shown in Table 5. Males also placed an importance on Lifelong durability as well. The feature of furniture that both groups gave the least importance to, which was also consistent with each gender, was Knock down furniture.

Table 5. Comparative table of priority furniture characteristic between gender groups.

\begin{tabular}{|c|c|c|c|c|c|c|}
\hline \multirow{2}{*}{ Dependent variables } & \multicolumn{3}{|c|}{ Male $(\mathrm{N}=22)$} & \multicolumn{3}{|c|}{ Female $(\mathrm{N}=28)$} \\
\hline & Mean & S.D. & Priority & Mean & S.D. & Priority \\
\hline Functionality & 4.95 & .213 & 1 & 4.96 & .189 & 1 \\
\hline Design (shape, color) & 4.27 & .456 & 4 & 4.21 & .686 & 5 \\
\hline Lifelong durability & 4.23 & .429 & 5 & 4.71 & .460 & 2 \\
\hline Size that is suitable for space & 4.82 & .501 & 2 & 4.71 & .460 & 2 \\
\hline Lightweight, easy to move & 3.82 & .733 & 7 & 3.64 & 1.129 & 7 \\
\hline Quality of materials & 4.41 & .503 & 3 & 4.39 & .832 & 3 \\
\hline Ease of maintenance, cleaning & 4.23 & .429 & 5 & 4.25 & .799 & 4 \\
\hline Have spare parts, equipment to upgrade, repair & 3.86 & .710 & 6 & 4.14 & .932 & 6 \\
\hline Finished furniture & 3.77 & .528 & 8 & 4.14 & .651 & 6 \\
\hline Knock down furniture & 2.77 & .528 & 9 & 2.61 & 1.031 & 8 \\
\hline
\end{tabular}

The comparative analysis results of the level of importance for providing services, between the gender variable, showed that males and females have the highest level of importance in terms of the features of furniture products to the same 2 aspects, which are (1) Maintenance services; and (2) Transportation support as shown in Table 6. Males also placed an importance regarding Taking back, product returns / Sales second hand in the highest range; whereas, females also placed an importance regarding Updates/Upgrade Services.

Table 6. Comparative table of the priority of customer service oriented factors between gender groups.

\begin{tabular}{|c|c|c|c|c|c|c|}
\hline \multirow[t]{2}{*}{ Dependent variables } & \multicolumn{3}{|c|}{ Male $(\mathrm{N}=22)$} & \multicolumn{3}{|c|}{ Female $(\mathrm{N}=28)$} \\
\hline & Mean & S.D. & Priority & Mean & S.D. & Priority \\
\hline \multicolumn{7}{|l|}{ Design stage / Pre-purchase } \\
\hline Support services during design (materials can be assign their own furniture) & 4.00 & .816 & 8 & 4.21 & 1.031 & 11 \\
\hline Services at the point of sale & 4.14 & .468 & 7 & 4.36 & .559 & 8 \\
\hline Leasing, Renting, Sharing and Pooling services & 3.59 & .590 & 12 & 3.89 & .786 & 12 \\
\hline Financial services & 4.18 & .733 & 6 & 4.25 & .441 & 10 \\
\hline Support transportation & 4.68 & .477 & 2 & 4.82 & .390 & 2 \\
\hline \multicolumn{7}{|l|}{ Use stage } \\
\hline Installation services, furniture design plan & 3.55 & .912 & 13 & 4.57 & .504 & 5 \\
\hline Maintenance services & 4.59 & .503 & 3 & 4.89 & .315 & 1 \\
\hline
\end{tabular}


Help Desk - hot line on product

Spare parts and consumables Delivery

Updates/upgrades Services

Extended warranty

End of life stage

End-of-life product management services (EOL services) such as removal

Material recycling

Take back, product returns / Sales second hand

\begin{tabular}{rrrrrr}
3.95 & .653 & 9 & 4.61 & .497 & 4 \\
4.50 & .512 & 4 & 4.75 & .441 & 3 \\
3.86 & .774 & 11 & 4.50 & 1.072 & 6 \\
3.91 & .684 & 10 & 4.32 & .670 & 9 \\
& & & & & \\
4.45 & .596 & 5 & 3.68 & 1.307 & 13 \\
4.77 & .429 & 1 & 4.43 & .790 & 7 \\
\hline
\end{tabular}

The overall analysis found that the average of the level of importance in providing service from the furniture company in each period of the lifetime of furniture in females was higher than the average of males in 2 aspects, which are (1) providing service in the Design stage, Pre-purchase; and (2) providing service in the Use stage, except (3) providing service in the End of life stage in which males considered this more important with a higher average than females. From the data analysis by using a t-test, it is found that males and females have a different level of placing importance on each period of the lifetime of the product with a statistical significance of $0.05\left(p<.05=.000^{*}\right)$ in Use stage and End of life stage.

Table 7. Table shows the mean and standard deviation on the priority of customer service oriented factors in each period of product lifecycle between gender groups.

\begin{tabular}{lccccc}
\hline Period of Product Lifecycle & \multicolumn{2}{c}{ Male (N=22) } & \multicolumn{2}{c}{ Female (N=28) } & \multirow{2}{*}{$t$-value } \\
\cline { 2 - 5 } & Mean & S.D. & Mean & S.D. & -1.917 \\
Design stage, Pre-purchase & 4.11 & .228 & 4.30 & .453 & .062 \\
Use stage & 4.06 & .413 & 4.60 & .305 & $-5.382^{*}$ \\
End of life stage & 4.61 & .434 & 4.05 & .671 & $.000^{*}$ \\
\hline
\end{tabular}

\subsection{Conclusion}

The findings of the study reveal that the majority of consumers have a tendency and to using furniture, The consumers are aware of the impact on the environment at a moderate level. The Environmental Awareness and Attitudes of consumers toward the trends and needs of furniture in different aspects are summarized as follows: (1) Dematerialization (2) Effective usage furniture (3) Reducing the impact on the environment such as chemical pollution, increasing the amount of waste and The use of energy. (4) Services were supporting the product, Consumers have a high level of demand. The tendency of providing additional services from the furniture they buy in the future is most likely to be.The reduction of the environmental problems based on the above-mentioned principles will promote the efficient use of products and sustainable consumption behaviour.The comparative analysis results from the gender variable found that, of the sample, who were business executives or who have the authority to make furniture buying decision, males had a higher tendency of awareness of the effect to the environment through the behaviour of using furniture than females in all four aspects. The survey results of the basic features for consumers buying furniture found that the major reason for consumers to buy new furniture was the need to replace worn-out old furniture, followed by the need to buy new furniture to improve corporate image and the aesthetics of the place. On average, consumers buy new furniture within three years/time with the behaviour of searching for information on social media from the website of the furniture brand in 2-3 stores. It is found that the furniture that consumers are mostly interested in buying is office furniture, followed by furniture that focuses on using natural materials. Lastly, for the payment method, the majority of consumers favour paying by credit card. The biggest problem that is found after using the furniture for three years is spare-parts that is worn-out, the deterioration of the materials in which the furniture company does not give support in fixing and when there is no service in delivering the spare parts to customers. Therefore, the approach for the Maintenance services, Transportation support and Take back, product returns / Sales second hand are the approaches in providing additional services that the majority of customers give more attention.

In the next research, the researcher is studying the relationship of building a strategy that combines the product and services for business corporation customers in more detail so that designers and furniture business entrepreneurs can use it as a guideline to design and create a business strategy that is sustainable with the environment. Therefore, for future research, the researcher suggests that the sample should be specified to be a variety of business types involving the government sector and the private sector for distinctness and more effective results.

\subsection{Acknowledgements}

The author would like to thank my dissertation advisor, Prof.Dr.Yanin Rugwongwan and Dr. Wichitra Singhirunnusorn, for invaluable help and constant encouragement throughout my research and the kindness in editing my English paper. Also, I would like to thank the faculty of Architecture, King Mongkut's Institute of Technology Ladkrabang, all friends Multidisciplinary program and those whose names are not mentioned here but have significantly inspired and encouraged me throughout this course. 


\subsection{References}

Ala-Kurikka, S. (2015) ENDS Europe [online]. Retrieved October 25, 2017, from http://www.endseurope.com/article/39711/electronic-goods-life-spans-shrinkingstudyindicates.

Brezet, JC., Bijma, A.S.,\& Ehrenfeld, J. (2001). The Design of Eco-Efficient Services; Method, Tools and Review of the Case Study Based 'Designing Eco-Efficient Services' Project. Ministry of VROM-Delft University of Technology

Fishbein, Bette; Ehrenfeld, John; Young, John (2000). Extended Producer Responsibility: A Materials Policy for the 21st Century

Kenan Institute Asia. (2009). "Final Report Economic Contributions of Thailand's Creative Industries".

Manzini, E., Vezzoli, C. (2003). A strategic design approach to develop sustainable product service systems: examples taken from the 'environmentally friendly innovation' Italian prize. Journal of Cleaner Production 11 (8), 851-857.Oksana, M. (2004). Product-service system: panacea or myth? PhD thesis. IIIEE,Lund University,Sweden.

Perner, L., (2010). Consumer behavior: the psychology of marketing. Retrieved July 2, 2017, from http://www.consumerpsychologist.com/

Tukker, A., Tischner, U. (2006). New Business for Old Europe: Product-service Development, Competitiveness and Sustainability. Greenleaf Publishing, Sheffield. UEA.2004. e Federation of European Furniture manufacturers. "The furniture waste site". Retrieved March 14, 2016, from http://www.ueanet.com/furniturewaste /frame4.htm. 